This item was submitted to Loughborough's Research Repository by the author.

Items in Figshare are protected by copyright, with all rights reserved, unless otherwise indicated.

\title{
Fat free mass explains the relationship between stunting and energy expenditure in urban Mexican Maya children
}

PLEASE CITE THE PUBLISHED VERSION

http://dx.doi.org/10.3109/03014460.2012.714403

\section{PUBLISHER}

(C) Informa Plc.

\section{VERSION}

AM (Accepted Manuscript)

\section{LICENCE}

CC BY-NC-ND 4.0

\section{REPOSITORY RECORD}

Wilson, Hannah J., Federico Dickinson, Daniel J. Hoffman, Paula L. Griffiths, Barry Bogin, and Maria Ines Varela Silva. 2019. "Fat Free Mass Explains the Relationship Between Stunting and Energy Expenditure in Urban Mexican Maya Children". figshare. https://hdl.handle.net/2134/14019. 
This item was submitted to Loughborough's Institutional Repository (https://dspace.lboro.ac.uk/) by the author and is made available under the following Creative Commons Licence conditions.

\section{creative
commons}

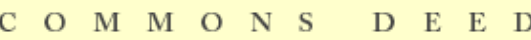

Attribution-NonCommercial-NoDerivs 2.5

You are free:

- to copy, distribute, display, and perform the work

Under the following conditions:

Attribution. You must attribute the work in the manner specified b the author or licensor.

Noncommercial. You may not use this work for commercial purposes.

No Derivative Works. You may not alter, transform, or build upon this work.

- For any reuse or distribution, you must make clear to others the license terms of this work.

- Any of these conditions can be waived if you get permission from the copyright holder.

Your fair use and other rights are in no way affected by the above.

This is a human-readable summary of the Leqal Code (the full license).

\section{Disclaimer 만}

For the full text of this licence, please go to: http://creativecommons.org/licenses/by-nc-nd/2.5/ 
3

4 5
Fat free mass explains the relationship between stunting and energy expenditure in urban Mexican Maya children

Hannah J. Wilson ${ }^{1}$, Federico Dickinson ${ }^{1,2}$, Daniel J Hoffman ${ }^{3}$, Paula L Griffiths ${ }^{1}$, Barry Bogin $^{1}$, Maria Inês Varela-Silva ${ }^{1}$

${ }^{1}$ School of Sport, Exercise and Health Sciences, Loughborough University, Loughborough, U.K.

${ }^{2}$ Departamento de Ecología Humana, Centro de Investigación y de Estudios

Avanzados del Instituto Politécnico Nacional (Cinivestav)-Unidad Mérida, 97310 Mérida, Yucatán, México

${ }^{3}$ Department of Nutritional Sciences, Rutgers University, New Brunswick, NJ, USA.

This study was funded by the Wenner-Gren Foundation: \#ICRG-93.

\section{Abstract}

Background: Childhood stunting has been associated with an increased risk of obesity in adulthood, but the causes are unclear. We hypothesize that stunting significantly reduces both resting and activity energy expenditure.

Aim: To assess and describe energy expenditure of low socio-economic Maya children and to determine whether stunting is independently related to energy expenditure after controlling for lean mass.

Subjects and Methods: 33 urban Maya children, 17 boys, aged 7-9 years, living in Merida, Mexico were measured for height, weight and bioelectrical impedance analysis (BIA). Body composition was estimated from BIA. Energy expenditure was measured for one week using the Actiheart (combined heart rate and accelerometer).

Results: Stunting affected $35 \%$ of these physically active children. Using multiple linear regression analysis, greater lean body mass predicted higher resting and activity energy expenditure. Stature was not a significant predictor of resting energy expenditure. A lower height-for-age z-score, but not stunting as a categorical variable, significantly predicted lower activity energy expenditure. 
Conclusion: Our hypothesis that stunting reduces total energy expenditure

2 (resting + active) in children is not supported. Rather children with shorter stature and less lean body mass have lower total energy expenditure. Complex interactions between body size, body composition and metabolic activity appear to elevate the risk for later life obesity in these Maya children.

\section{Introduction}

Middle-income countries, such as Mexico and Brazil, are currently experiencing a rise in obesity levels among their poor (Mendez et al. 2005; Popkin et al. 2012). It is possible that this rise in obesity is following the pattern shown in populations in high income countries as globalized diets and lifestyles are adopted by the populations of lower income nations (Adair and Popkin 2005; Barquera et al. 2008; Caballero 2007; Popkin et al. 2012). However, additional causes for this rise in obesity may exist. Trends toward urbanisation, including rural-to-urban migration, with associated changes in physical activity are a possible cause (Katzmarzyk and Mason 2009; Monda et al. 2007; Parra et al. 2009). In addition, the most impoverished segments of lesser-developed nations may have experienced a relatively rapid and acute shift from general protein-energy under-nutrition to a more complex mix of under-supply of specific amino acids, vitamins and minerals along with concurrent over-supply of energy. There is indirect evidence from research with adults indicating that this change in the nature of malnutrition is accompanied by metabolic shifts, such as reduced fat oxidation with increased risk of overweight/obesity (Florencio et al. 2003; Leonard et al. 2009).

Low SES, urban, Maya children are the focus of this study. Maya living in the Mexican Yucatan Peninsula are currently undergoing nutrition transition (Leatherman and Goodman 2005; Leatherman et al. 2010) and are a double burdened population, with simultaneously high rates of stunting and overweight and obesity (Azcorra et al. 2009; Dickinson 1997; Varela Silva et al. 2012).

\section{A. Stunting and energy expenditure}

Stunted and short height-for-age individuals may be at an increased risk of overweight or obesity (OW/OB) during the growing years compared with their non- 
1 stunted peers (Bogin and Loucky 1997; Corvalan et al. 2008; Hoffman et al. 2007;

2 Mardones et al. 2008; Martins et al. 2004; Smith et al. 2003; Walker et al. 2007).

3 Changes in resting metabolic rate (RMR) occur during the first five years of life

4 (Grillo et al. 2005) the same period that stunting most often occurs (Fox and Hillsdon

5 2007). A decreased metabolism could be an efficient method of adapting to energy

6 requirements in response to low caloric availability. Yet a slowing of the metabolism

7 places individuals at an increased risk of weight gain in conditions of caloric

8 abundance. Preliminary evidence suggests that metabolic shifts may be associated

9 with the risk for obesity in stunted children (Grillo et al. 2005; Hoffman et al. 2000; Soares-Wynter and Walker 1996; Wren et al. 1997) but the exact conditions this relationship requires have yet to be fully understood. The present study attempts to objectively estimate urban Maya children's RMR and determine whether it is influenced by stunting status.

\section{B. Modernization and activity energy expenditure}

The changes in behaviour that occur as part of urbanization and modernisation may play a substantial role in nutrition-related, non-communicable diseases. The behavioural transition, associated with modernisation and the nutrition transition, is characterised by an increase in sedentary activity (Onywera 2010) and reduced occupational physical activity (Huneault et al. 2011; Popkin et al. 2002) in adults. Low levels of activity energy expenditure (AEE) and physical activity are risk factors for obesity (Fox and Hillsdon 2007; Gomez et al. 2007; Monda et al. 2008).

The relationship between physical activity and adiposity or OW/OB in children living in developing countries has been less studied compared to adults in the same environments and children in developed countries (DepartHealth 2004). Research with Latin American and Mexican children has found an increase in sedentary behaviour, such as television viewing (Hernandez et al. 1999; Malina et al. 2008; Sauri Bazán 2003). However frequent participation in sedentary activities does not necessarily result in low physical activity levels (Biddle et al. 2004; Malina et al. 2008). Thus, it is not clear what the relationship is between children's physical activity and adiposity or OW/OB in the nutrition transition. This present study presents objective measurements of the physical activity and AEE of urban Maya children and classifies them for risk of negative health outcomes. 


\section{Actiheart}

This is one of the first studies to objectively assess energy expenditure using combined heart rate monitoring and accelerometry, the Actiheart, in free-living children in developing countries. A previous study has been performed in adolescents in urban Brazil (Victora et al. 2008). The Actiheart allows habitual physical activity to be assessed objectively and accurately (Assah et al. 2011; Corder et al. 2005) for up to 3 weeks at a time (Delisle 2008). The Actiheart was designed to minimize high discomfort and burden on the participant (ibid) and has been validated against double-labelled water (Catalano and Ehrenberg 2006) and indirect calorimetry (Brage et al. 2005; Corder et al. 2005). This makes it a very good tool for assessing free-living activity .

\section{Aims}

The purpose of this article is to report the physical activity levels of low SES, urban Maya children and to assess whether chronic under-nutrition (stunting) impacts their energy expenditure. We hypothesize that stunting significantly reduces both resting and activity energy expenditure, independently of lean mass.

\section{Methods}

\section{E. Sample}

The study design was cross-sectional and conducted between March and July 2010. This sample was composed of 7.00-9.99 year old urban Maya school children living in Merida, Yucatan, Mexico.

\section{F. Recruitment}

Schools located in the low SES neighbourhoods of southern Merida, known to contain a relatively high proportion of Maya families, wereselected. Children of Maya ethnicity, aged 7-9 years-old, were identified from school lists by having two Maya surnames, one from their mother and one from their father. The mothers were then invited to group information sessions at their children's schools where the nature of the study was verbally explained, in Spanish, and information sheets, in Spanish, were provided. The Maya living in the south of Merida were highly acculturated and all were comfortable speaking Spanish. 
Written informed consent was obtained from the mothers and verbal assent

2 from the children. Ethical clearance was obtained from the Loughborough University

3 Ethics Committee in the U.K. and the Bioethical Committee of CINVESTAV in

4 Mexico.

5

6

7

8

9

10

\section{G. Anthropometry}

Children underwent anthropometric measurements for stature (Gordon et al. 1988), weight (ibid), waist circumference (WC) (Callaway et al. 1988) and skinfolds (triceps and sub-scapular) (Harrison et al. 1988) using standard techniques. Body mass index (BMI) was calculated by dividing the child's weight in kilograms by their statures in metres squared. The technical error of measurement for anthropometry was not calculated. The research team received careful training both before and during the fieldwork.

The Comprehensive sex- and age-specific reference charts (Frisancho 2008) were used to calculate $\mathrm{z}$-scores for BMI and WC. The Comprehensive reference was chosen as it was created using data from the Third National Health and Nutrition Examination Survey (NHANES III) from the United States. NHANES III is a stratified, nationally representative sample of the US population, which over-sampled ethnic minorities. The percentage of participants according to ethnicity is: White (European-American) 34.4\%, Black (African-American) 26.8\%, Hispanic/Latino (mostly Mexican-American and Cuban) $27.0 \%$ and Other $4.3 \%$, with $7.5 \%$ missing an ethnic affiliation. NHANES III is, perhaps, the largest sampled, statistically validated growth reference that includes Mexican children. As such, it is the most appropriate for use with a Mexican population such as the Maya.

Children were classified as being stunted if their height-for-age was below the $5^{\text {th }}$ percentile.

\section{H. Bioelectrical impedance analysis}

Body composition was measured using bioelectric impedance analysis (BIA) with a BioScan 916 by (Maltron, UK). Percent body fat (\%BF) was calculated using the impedance and reactance values with equations specific for American Indian children (Equation 1) (Lohman et al. 1999) as the Maya are an indigenous American group. \%BF was converted into kilograms of body fat, which was used to calculate 
1 fat free mass (FFM). \%BF was compared against age- and sex-specific reference curves (Ogden et al. 2011). The technical error of measurement for BIA was not calculated The research team received careful training in BIA both before and during the fieldwork.

Equation 1: Percentage body fat $=-0.49$ age +0.51 sex +0.44 weight +1.55 triceps skinfold +0.15 subscapular skinfold +0.54 (stature $2 /$ resistance $)+0.13$ reactance -

$8 \quad$ 0.04triceps skinfold $x$ stature $2 /$ resistance -10.91

Definitions: Sex coded 1 for girls, 0 for boys. Weight is in $\mathrm{kg}$. Skinfold thicknesses are in $\mathrm{mm}$. Resistance and reactance are in ohms. Stature is in $\mathrm{m}$.

\section{Energy expenditure}

Physical activity of the children was measured for 7 days using an Actiheart, a combined heart rate and accelerometer (Corder et al. 2007; Corder et al. 2005; Wilson et al. 2011). Children were included in the analysis if they had at least 3 days usable data that included a minimum of 2 weekdays and 1 weekend day. A day was defined as a minimum of 10 hours of usable data during waking hours (Ward et al. 2005). Data was collected and analysed in minute-long epochs or sampling interval.

Energy expenditure was estimated using branched equation modelling in Actiheart software v.4.52. Data were cleaned by removing extended periods ( $>5$ minutes) in which the heart rate data was missing and also when there was a mismatch in the heart rate and accelerometry data, for example, extended periods of high accelerometry counts and low heart rates (but not the reverse). The software performed straight line interpolation for periods of missing heart rate data lasting up to 5 minutes, allowing energy expenditure to be estimated for these periods. The period of data removal was extended if 5 minutes of missing heart rate data was preceded or followed by one minute of heart rate data and then another period of missing heart rate data.

Resting energy expenditure (REE), activity energy expenditure (AEE) and total energy expenditure (TEE) were used in the analyses. All variables were calculated using predictive equations with an external reference curve created using 13 year old British children (Corder et al. 2005). The error introduced into the sample through using an external group calibration curve is likely similar across the sample, as the sample is fairly genetically homogeneous and has experienced similar chronic 
1 environmental conditions. However the error introduced by this method of estimation

2 is probably too high for direct comparisons with external samples.

REE was calculated using the Schofield equation (Schofield 1985). Sleeping

4 heart rate was individually calculated for each child using the average heart rate

5 during extended periods ( $>2$ hours) of negligible accelerometry counts during night

6 hours (12 pm to $9 \mathrm{am}$ ). AEE was calculated when the heart rate was above sleeping

7 heart rate. TEE was calculated as the additive combination of REE, AEE and diet

8 induced thermogenesis.

For assessment of the level of physical activity in which the children engaged, metabolic equivalent (MET) was calculated by the Actiheart software. The time at each MET was used to classify the activity level of each minute-long epoch as low $(\mathrm{MET}<3)$ or moderate-to-vigorous (MET $\geq 3$ ).

\section{J. Statistical analysis}

Normality of the distribution of all variables was checked using KolmogorovSmirnov test and skewness and kurtosis. Independent $t$-tests were used to compare chronic nutritional status (stunted v. non-stunted) and sex with anthropometric, body composition and energy expenditure variables. Energy expenditure variables were linearly regressed onto BMI Z-score and WC z-scores and body composition variables. Independent $t$-tests were used to compare included and excluded children for anthropometric and body composition measures. Energy expenditure variables were not compared between included and excluded children because of the unreliability of the excluded measures. with measures of energy expenditure (REE, AEE and TEE) as the dependent variables. The independent variables were added in three steps: 1) FFM, 2) heightfor-age z-score or stunting and 3) sex. Normality of the residuals were checked All analyses were undertaken using PASW (SPSS) v.18.0. Significance was set a priori at $p<0.05$.

\section{Results}


From the 58 children recruited, 33 were included in the final analysis. Children were excluded for incomplete Actiheart data $(n=24)$ and health problems $(n=1)$. The reason for missing Actiheart data was primarily poor electrode adherence caused by high rates of sweating in the hot, humid climate. This resulted in missing heart rate data or the device falling off of the skin (Wilson et al. 2011). Also several Actihearts were broken during the course of the week. See Wilson et al. (2011) for a more complete description of the logistical difficulties encountered when attempting to use Actihearts in children. The included children were not statistically significantly different from excluded children for any measures of anthropometry or body composition (Table 1).

\section{Table 1 about here}

Overall these urban Mexican Maya children were short and except for the non-stunted girls had low weight-for-age z-scores (Table 2). Stunted children were significantly smaller in stature and weight, with lower estimated FFM and FM than their non-stunted peers. BMI Z-scores did not significantly differ between the stunted and non-stunted children. Using United States references based upon the NHANES III (1999-2004), the mean \%BF of the stunted girls is about the $17^{\text {th }}$ percentile, at about the $61^{\text {st }}$ percentile for the non-stunted girls and both stunted and non-stunted boys are at about the $53^{\text {rd }}$ percentile (Ogden et al. 2011).

\section{Table 2 about here}

Stunted children had lower levels of, REE, AEE and TEE (Table 3) compared to non-stunted children. Stunted children spent significantly more time in light physical activity and less time per day in moderate-to-vigorous physical activity (MVPA) than non-stunted children. No significant differences in REE, AEE or TEE were found between the sexes.

Overall, this sample of children was highly active, spending an average of 120 minutes per day in MVPA. However girls and stunted children spent significantly less time in MVPA compared to boys and non-stunted children, respectively. Of the five children who did not spend 60 minutes per day in MVPA, all were girls and four were stunted. The variation in time spent at each level of physical activity was high, with a range of 20-312 minutes per day spent in moderate-to-vigorous physical activity. 
3

4

5

In multiple linear regression models (Table 4), kilograms of FFM was the

6 largest predictor of all measures of energy expenditure (REE, AEE and TEE),

7 explaining between 33 and $81 \%$ of the variance in energy expenditures (Table 4).

8 Boys had significantly higher measures of all measures of energy expenditure than

9 girls. Neither height-for-age z-scores nor stunting were significant predictors of REE.

10 Height-for-age z-score but not stunting was a significant predictor for AEE and TEE.

11

12

Table 4 about here 


\section{Discussion}

Our hypothesis that stunting, per se, is associated with lower estimated energy expenditure (resting + activity) in children is not supported by the current study. Rather children with short stature, as a continuous variable, and lower fat free mass (FFM) have lower total energy expenditure (TEE) compared to taller children with higher FFM. This study of Maya children extends the understanding of the relationship between chronic under-nutrition and obesity risk by adjusting for the primary determinant of resting energy expenditure (REE), lean tissue. For these Maya children the lower absolute amount of FFM in the stunted children may mitigate other factors and result in a lower REE. The stunted children also have lower activity energy expenditure (AEE), a potential behavioural modification. The differences in behaviour according to stature are clearly revealed by the Actiheart data, which show that the stunted children engage in significantly less moderate-tovigorous activity than the non-stunted children. Lower REE and AEE lead to lower TEE and this may leave the stunted Maya children more susceptible to weight and fat gain if they ingest as much energy as the taller children. Metabolic shifts, such as one toward reduced fat oxidation, may exacerbate the risk of overweight and excessive fatness. We did not measure directly metabolic activity at the physiological level, and this needs to be done to better evaluate our findings in light of past research.

A statistically significant interaction between FFM, sex and height-of-age zscore was observed in all regression models. Compared with non-stunted boys and girls, stunted girls had a significantly lower REE and TEE than stunted boys (Table 3). Stunted girls also had 49\% lower MVPA than non-stunted girls (60 vs. 116.7 MET). In contrast, stunted boys had 31\% lower MVPA than non-stunted boys (113.6 vs. 164.25 MET).

Other studies have foundthat stunting has effects on energy expenditure. Soares-Wynter and Walker (1996) found lower REE in stunted Jamaican children aged 7-8 years old but did not report sex composition of the sample or differences between male and female children . Our findings are similar to those of Grillo et al. (2005) who found in a case-controlled study in the shantytowns of Sao Paulo, Brazil that stunted girls had lower resting energy expenditure than age- and weight-for- 
1 height matched, non-stunted girls. In the same Brazilian cohort, Martins et al. (2004) reported that stunted children had an increased \%BF and reduced \%FFM compared to their non-stunted, age- and weight-for-height matched peers. Our new results find a trend toward just the opposite for body composition in girls.

The AEE data from these Maya children also stand in contrast to the same stunted Brazilian children, which found equivalent AEEs in stunted and non-stunted children (Hoffman et al. 2000). Another study of rural indigenous children and urban children, all from poor families, in Oaxaca, Mexico found that stunted children exhibited similar fitness levels levels to non-stunted, adequately nourished children . It appears that the Mexican Maya children of our study have a different relationship between stunting and physical activity levels from the children in Sao Paulo and Oaxaca. From these data, it is not possible to know whether the lower levels of physical activity in the stunted Maya are driven by biological or socialprocesses. These urban Maya children can be considered very active, with $85 \%(n=28)$ spending at least one hour per day in moderate-to-vigorous physical activity. Recommendations are that children should be moderately to vigorously active for a minimum of 60 minutes a day (DepartHealth 2004) for independent reduction of chronic disease risk (Balas-Nakash et al. 2010; Bell et al. 2007). Even the stunted girls achieved on average 60 minutes per day of MVPA.

20 It is notable that the only children who failed to spend an hour a day in MVPA were girls. That the majority of these girls (4 of 5) were stunted is suggestive of a biosocial or biocultural relationship related to the sex of the child. It is likely that this sample of girls will become less active in adolescence (Dumith et al. 2011), increasing their risk for obesity in adulthood. The mothers of these children had very high levels of obesity (Varela Silva et al. 2012). Women who are both stunted and overweight place their own children at risk of negative health outcomes. Stunted mothers are more likely to have children who are low birth weight (Victora et al. 2008), who die before their fifth birthday (Monden and Smits 2009) and who are stunted (Delisle 2008). Overweight mothers are more likely to miscarry, have gestational diabetes and have children who are overweight (Catalano and Ehrenberg 2006). Thus a population with a large number of women with individual double burden faces a public health concern in for multiple generations facing cycles of ill health increasing 
. The applicability of the results of this study to other human groups is limited by the small sample size, the use of a group calibration curve for the energy expenditure estimation and a BIA predictive equation that was not specific to the Maya. Some strengths of this study are the variety of data collected simultaneously, especially the use of an objective and well-validated instrument, the Actiheart, to estimate energy expenditure. The cost and participant burden of traditional methods of objectively measuring energy expenditure have tended to limit their use in low income groups of developing countries, with self-reported physical activity being the preferred method.

\section{Conclusion}

Complex interactions between body size, body composition and metabolic activity appear to elevate the risk for current and later life obesity in this sample of Maya children. These children were found to be highly active but girls and stunted children exhibited the lowest level of physical activity. In this sample, shorter children were less active than taller children, and stunted children spent significantly less time in MVPA than non-stunted children. The effect of stature seems to be mediated via the lower FFM of the shorter/stunted children and not primarily due to the stunting. Even so, an important point to make here is that lower FFM is associated with short stature/stunting and public health workers and policy planners may still use short stature as a proxy for higher risk of negative health outcomes.

\section{Acknowledgements}

The authors would like to thank the members of our field-team; Maria Luis Avila, Hugo Azcorra, Sally López, Jenice Tut Be and Adriana Vázquez Vázquez, without whose assistance and time this research would not have been possible; the school directors and mothers who welcomed us into their community and homes; Conacyt for funding FD's sabbatical year to Loughborough University (fellowship number 166138) and the School of Sport, Exercise and Health Sciences at Loughborough University for hosting FD during sabbatical. 


\section{Literature cited}

Adair LS, and Popkin BM. 2005. Are child eating patterns being transformed globally? Obesity Research 13(7):1281-1299.

Assah FK, Ekelund U, Brage S, Wright A, Mbanya JC, and Wareham NJ. 2011. Accuracy and validity of a combined heart rate and motion sensor for the measurement of free-living physical activity energy expenditure in adults in Cameroon. International Journal of Epidemiology 40(1):112-120.

Azcorra H, Dickinson F, and Rothenberg SJ. 2009. Family Migration and Physical Growth in Merida, Yucatan, Mexico. American Journal of Human Biology 21(3):398-400.

Balas-Nakash M, Benitez-Arciniega A, Perichart-Perera O, Valdes-Ramos R, and Vadillo-Ortega F. 2010. The effect of exercise on cardiovascular risk markers in Mexican school-aged children: comparison between two structured group routines. Salud Publica De Mexico 52(5):398-405.

Barquera S, Hernandez-Barrera L, Tolentino ML, Espinosa J, Ng SW, Rivera JA, and Popkin BM. 2008. Energy Intake from Beverages Is Increasing among Mexican Adolescents and Adults. Journal of Nutrition 138(12):2454-2461.

Bell LM, Watts K, Siafarikas A, Thompson A, Ratnam N, Bulsara M, Finn J, O'Driscoll G, Green DJ, Jones TW and others. 2007. Exercise alone reduces insulin resistance in obese children independently of changes in body composition. J Clin Endocrinol Metab 92(11):4230-4235.

Biddle SJ, Gorely T, and Stensel DJ. 2004. Health-enhancing physical activity and sedentary behaviour in children and adolescents. J Sports Sci 22(8):679-701.

Bogin B, and Loucky J. 1997. Plasticity, political economy, and physical growth status of Guatemala Maya children living in the United States. Am J Phys Anthropol 102(1):17-32.

Brage S, Brage N, Franks PW, Ekelund U, and Wareham NJ. 2005. Reliability and validity of the combined heart rate and movement sensor Actiheart. European Journal of Clinical Nutrition 59(4):561-570.

Caballero B. 2007. The global epidemic of obesity: an overview. Epidemiol Rev 29:15.

Callaway C, Cameron Chumlea W, Bouchard C, Himes H, Lohman T, Martin A, Mitchell C, Mueller W, Roche A, and Seefeldt V. 1988. Circumferences. In: Lohman T, Roche A, and Martorell R, editors. Anthropometric standardization reference manual. Champaign, IL: Human Kinetics Books. p 39-54.

Catalano P, and Ehrenberg H. 2006. The short- and long-term implications of maternal obesity on the mother and her offspring. BJOG 113:1126-1133.

Corder K, Brage S, Mattocks C, Ness A, Riddoch C, Wareham NJ, and Ekelund U. 2007. Comparison of two methods to assess PAEE during six activities in children. Med Sci Sports Exerc 39(12):2180-2188.

Corder K, Brage S, Wareham NJ, and Ekelund U. 2005. Comparison of PAEE from combined and separate heart rate and movement models in children. Med Sci Sports Exerc 37(10):1761-1767.

Corvalan C, Uauy R, Flores R, Kleinbaum D, and Martorell R. 2008. Reductions in the energy content of meals served in the Chilean National Nursery School Council Program did not consistently decrease obesity among beneficiaries. Journal of Nutrition 138(11):2237-2243. 
Delisle HF. 2008. Poverty: the double burden of malnutrition in mothers and the intergenerational impact. Annals of the New York Academy of Sciences 1136:172-184.

DepartHealth. 2004. At least five a week. In: Department of Health PA, Health Improvement and Prevention, editor. London.

Dickinson F. 1997. Desnutrición y obesidad en poblaciones Yucatecas. In: Aréchiga Viramontes J, and Bertran Vilá M, editors. Significación Sociocultural de la Variación Morfológica. México, D. F.: Universidad Nacional Autónoma de México. p 69-88.

Dumith SC, Gigante DP, Domingues MR, and Kohl HW, 3rd. 2011. Physical activity change during adolescence: a systematic review and a pooled analysis. International Journal of Epidemiology 40(3):685-698.

Florencio TT, Ferreira HS, Cavalcante JC, Luciano SM, and Sawaya AL. 2003. Food consumed does not account for the higher prevalence of obesity among stunted adults in a very-low-income population in the Northeast of Brazil (Maceio, Alagoas). European Journal of Clinical Nutrition 57(11):1437-1446.

Fox KR, and Hillsdon M. 2007. Physical activity and obesity. Obes Rev 8 Suppl 1:115-121.

Frisancho AR. 2008. Anthropometric standards: an interactive nutritional reference of body size and body comosition for children and adults. Ann Arbor, Michigan: University of Michigan Press. $335 \mathrm{p}$.

Gomez LF, Parra DC, Lobelo F, Samper B, Moreno J, Jacoby E, Lucumi DI, Matsudo S, and Borda C. 2007. Television viewing and its association with overweight in Colombian children: results from the 2005 National Nutrition Survey: a cross sectional study. Int J Behav Nutr Phys Act 4:41.

Gordon C, Chumlea C, and Roche A. 1988. Stature, recumbent length and weight. In: Lohman T, Roche A, and Martorell R, editors. Antrhopometric standardization reference manual (abridged edition). Champaign, IL: Human Kinetics. p 3-8.

Grillo LP, Siqueira AFA, Silva AC, Martins PA, Verreschi ITN, and Sawaya AL. 2005. Lower resting metabolic rate and higher velocity of weight gain in a prospective study of stunted vs nonstunted girls living in the shantytowns of Sao Paulo, Brazil. European Journal of Clinical Nutrition 59(7):835-842.

Harper C, Marcus R, and Moore K. 2003. Enduring poverty and the conditions of childhood: Lifecourse and intergenerational poverty transmissions. World Development 31(3):535-554.

Harrison G, Buskirk E, Carter J, Johnston F, Lohman T, Pollock M, Roche A, and Wilmore J. 1988. Skinfold thicknesses and measurement techniques. In: Lohman T, Roche A, and Martorell R, editors. Anthropometric standardization reference manual. Champaign, IL: Human Kinetics Books. p 55-70.

Hernandez B, Gortmaker SL, Colditz GA, Peterson KE, Laird NM, and ParraCabrera S. 1999. Association of obesity with physical activity, television programs and other forms of video viewing among children in Mexico city. Int J Obes Relat Metab Disord 23(8):845-854.

Hoffman DJ, Martins PA, Roberts SB, and Sawaya AL. 2007. Body fat distribution in stunted compared with normal-height children from the shantytowns of Sao Paulo, Brazil. Nutrition 23(9):640-646.

Hoffman DJ, Sawaya AL, Coward WA, Wright A, Martins PA, de Nascimento C, Tucker KL, and Roberts SB. 2000. Energy expenditure of stunted and 
nonstunted boys and girls living in the shantytowns of Sao Paulo, Brazil. Am J Clin Nutr 72(4):1025-1031.

Huneault L, Mathieu ME, and Tremblay A. 2011. Globalization and modernization: an obesogenic combination. Obes Rev 12(5):e64-72.

Katzmarzyk PT, and Mason C. 2009. The physical activity transition. J Phys Act Health 6(3):269-280.

Leatherman TL, and Goodman A. 2005. Coca-colonization of diets in the Yucatan. Social Science \& Medicine 61(4):833-846.

Leatherman TL, Goodman AH, and Stillman T. 2010. Changes in stature, weight, and nutritional status with tourism-based economic development in the Yucatan. Econ Hum Biol 8(2):153-158.

Leonard WR, Sorensen MV, Mosher MJ, Spitsyn V, and Comuzzie AG. 2009. Reduced Fat Oxidation and Obesity Risks Among the Buryat of Southern Siberia. American Journal of Human Biology 21(5):664-670.

Lohman TG, Caballero B, Himes JH, Hunsberger S, Reid R, Stewart D, and Skipper B. 1999. Body composition assessment in American Indian children. American Journal of Clinical Nutrition 69(4 Suppl):764S-766S.

Malina RM, Reyes ME, Tan SK, and Little BB. 2008. Physical activity in youth from a subsistence agriculture community in the Valley of Oaxaca, southern Mexico. Appl Physiol Nutr Metab 33(4):819-830.

Mardones F, Villarroel L, Karzulovic L, Barja S, Arnaiz P, Taibo M, and MardonesRestat F. 2008. Association of perinatal factors and obesity in 6-to 8-year-old Chilean children. International Journal of Epidemiology 37(4):902-910.

Martins PA, Hoffman DJ, Fernandes MTB, Nascimento CR, Roberts SB, Sesso R, and Sawaya AL. 2004. Stunted children gain less lean body mass and more fat mass than their non-stunted counterparts: a prospective study. British Journal of Nutrition 92(5):819-825.

Mendez MA, Monteiro CA, and Popkin BM. 2005. Overweight exceeds underweight among women in most developing countries. Am J Clin Nutr 81(3):714-721.

Monda KL, Adair LS, Zhai F, and Popkin BM. 2008. Longitudinal relationships between occupational and domestic physical activity patterns and body weight in China. Eur J Clin Nutr 62(11):1318-1325.

Monda KL, Gordon-Larsen P, Stevens J, and Popkin BM. 2007. China's transition: The effect of rapid urbanization on adult occupational physical activity. Social Science \& Medicine 64(4):858-870.

Monden CWS, and Smits J. 2009. Maternal Height and Child Mortality in 42 Developing Countries. American Journal of Human Biology 21(3):305-311.

Ogden CL, Li Y, Freedman DS, Borrud LD, and Flegal KM. 2011. Smoothed Percentage Body Fat Percentiles for U.S. Children and Adolescents, 19992004. National Health Statistics Reports 43(November 9, 2011):1-7.

Onywera VO. 2010. Childhood obesity and physical inactivity threat in Africa: strategies for a healthy future. Glob Health Promot 17(2 Suppl):45-46.

Parra DC, Lobelo F, Gomez LF, Rutt C, Schmid T, Brownson RC, and Pratt M. 2009. Household motor vehicle use and weight status among Colombian adults: Are we driving our way towards obesity? Preventive Medicine 49(2-3):179-183.

Popkin BM, Adair LS, and Ng SW. 2012. Global nutrition transition and the pandemic of obesity in developing countries. Nutr Rev 70(1):3-21.

Popkin BM, Lu B, and Zhai F. 2002. Understanding the nutrition transition: measuring rapid dietary changes in transitional countries. Public Health Nutr 5(6A):947-953. 
Sauri Bazán MC. 2003. Publicidad televisiva, hábitos alimentarios y salud en adolescentes de la ciudad de Mérida Mérida, México: Centro de Investigación y de Estudios Avanzados del I. P. N.

Schofield WN. 1985. Predicting basal metabolic rate, new standards and review of previous work. Hum Nutr Clin Nutr 39 Suppl 1:5-41.

Smith PK, Bogin B, Varela-Silva MI, and Loucky J. 2003. Economic and anthropological assessments of the health of children in Maya immigrant families in the US. Econ Hum Biol 1(2):145-160.

Soares-Wynter SY, and Walker SP. 1996. Resting metabolic rate and body composition in stunted and nonstunted children. American Journal of Clinical Nutrition 64(2):137-141.

Varela Silva MI, Dickinson F, Wilson H, Azcorra H, Griffiths P, and Bogin B. 2012. The nutritional dual-burden in developing countries. How is it assessed and what are the health implications? Collegium Anthropologicum in press.

Victora CG, Adair L, Fall C, Hallal PC, Martorell R, Richter L, and Sachdev HS. 2008. Maternal and child undernutrition: consequences for adult health and human capital. Lancet 371(9609):340-357.

Walker SP, Chang SM, and Powell CA. 2007. The association between early childhood stunting and weight status in late adolescence. Int J Obes (Lond) 31(2):347-352.

Ward DS, Evenson KR, Vaughn A, Rodgers AB, and Troiano RP. 2005. Accelerometer use in physical activity: best practices and research recommendations. Med Sci Sports Exerc 37(11 Suppl):S582-588.

Wilson H, Dickinson F, Griffiths P, Bogin B, and Varela-Silva MI. 2011. Logistics of using the Actiheart physical activity monitors in urban Mexico among 7- to 9year-old children. American Journal of Human Biology 23(3):426-428.

Wren RE, Blume H, Mazariegos M, Solomons N, Alvarez JO, and Goran MI. 1997. Body composition, resting metabolic rate, and energy requirements of shortand normal-stature, low-income Guatemalan children. American Journal of Clinical Nutrition 66(2):406-412. 
1 Table 1 Comparison of body composition and anthropometric measurements of

2 included and excluded urban Maya children

\begin{tabular}{|c|c|c|c|}
\hline & Included & Excluded & All \\
\hline N (\%) & 33 & 25 & $58(100)$ \\
\hline Boys, n (\%) & $17(51.5)$ & $14(56.0)$ & $31(53.4)$ \\
\hline Age & $8.34(0.82)$ & $8.52(0.75)$ & $8.42(0.79)$ \\
\hline Stature $(\mathrm{cm})$ & $121.41(6.96)$ & $123.08(6.64)$ & $122.13(6.82)$ \\
\hline $\begin{array}{l}\text { Stature Z- } \\
\text { score }^{1}\end{array}$ & $-1.19(0.92)$ & $-1.10(0.79)$ & $-1.15(0.86)$ \\
\hline Weight (kg) & $26.14(6.96)$ & $27.85(5.76)$ & $26.87(6.47)$ \\
\hline $\begin{array}{l}\text { Weight z- } \\
\text { score }^{1}\end{array}$ & $-0.52(0.89)$ & $-0.35(0.88)$ & $-0.45(0.88)$ \\
\hline BMI $\left(\mathrm{kg} / \mathrm{m}^{2}\right)$ & $17.48(2.97)$ & 18.28 (3.19) & $17.83(3.07)$ \\
\hline BMI z-score & $0.45(0.90)$ & $0.68(1.01)$ & $0.56(0.95)$ \\
\hline WC (cm) & $58.90(7.87)$ & $60.93(7.70)$ & $59.77(7.80)$ \\
\hline WC z-score ${ }^{1}$ & $0.28(0.75)$ & $0.43(0.84)$ & $0.34(0.79)$ \\
\hline FFM (kg) ${ }^{2}$ & $18.43(2.96)$ & $19.58(2.83)$ & $18.96(2.95)$ \\
\hline $\mathrm{FM}(\mathrm{kg})^{2}$ & $7.71(4.40)$ & $8.27(3.32)$ & $8.00(3.97)$ \\
\hline$\% F F M^{2}$ & 72.19 (7.53) & $71.38(6.31)$ & $71.84(6.98)$ \\
\hline$\% \mathrm{BF}^{2}$ & $27.81(7.53)$ & $28.62(6.31)$ & $28.23(7.03)$ \\
\hline
\end{tabular}

${ }^{1}$ Age and sex specific z-scores based upon NHANES III using Frisancho's Comprehensive reference (2008).

$5 \quad{ }^{2}$ Calculated using an equation for American Indian children including bioelectrical impedance and 6 anthropometry (Lohman et al 1999).

7 No significant differences found between included and excluded using independent t-tests

8

9

10

11

12

13

14

15

16

17

18

19

20

21

22

23

24 


\begin{tabular}{|c|c|c|c|c|c|}
\hline & \multicolumn{2}{|c|}{ Stunted } & \multicolumn{2}{|c|}{ Non-Stunted } & \multirow{2}{*}{ All } \\
\hline & Boys & Girls & Boys & Girls & \\
\hline N (\%) & $5(15.2)$ & $6(18.2)$ & $12(36.4)$ & $10(30.3)$ & $33(100)$ \\
\hline Age & $8.24(0.93)$ & $8.27(0.96)$ & $8.20(0.86)$ & $8.60(0.71)$ & $8.34(0.82)$ \\
\hline Stature $(\mathrm{cm})^{a}$ & $114.46(4.25)$ & $115.23(7.91)$ & $123.47(4.22)$ & $126.12(5.02)$ & $\begin{array}{l}121.41 \\
(6.96)\end{array}$ \\
\hline $\begin{array}{l}\text { Stature z- } \\
\text { score }^{2, a}\end{array}$ & $-2.38(0.53)$ & $-2.02(0.45)$ & $-0.71(0.68)$ & $-0.66(0.57)$ & $-1.19(0.92)$ \\
\hline Weight $(\mathrm{kg})^{\mathrm{a}}$ & $22.56(3.27)$ & $20.89(4.77)$ & 26.15 (5.11) & 31.05 (8.37) & $26.14(6.96)$ \\
\hline $\begin{array}{l}\text { Weight z- } \\
\text { score }^{2, a}\end{array}$ & $-1.17(0.58)$ & $-1.17(0.41)$ & $-0.49(0.85)$ & $0.17(0.79)$ & $-0.52(0.89)$ \\
\hline BMI $\left(\mathrm{kg} / \mathrm{m}^{2}\right)$ & $17.13(1.50)$ & $15.60(1.91)$ & $17.06(2.53)$ & $19.28(3.79)$ & $17.48(2.98)$ \\
\hline BMI z-score & $0.48(0.58)$ & $-0.25(0.73)$ & $0.44(0.91)$ & $0.87(0.95)$ & $0.45(0.90)$ \\
\hline $\mathrm{FFM}^{3, \mathrm{a}}$ & $16.51(1.84)$ & $15.88(3.13)$ & $18.98(1.79)$ & $20.24(3.12)$ & $18.43(2.96)$ \\
\hline$\% F F M^{3}$ & 73.81 (7.49) & $76.37(3.71)$ & 73.79 (7.18) & $66.96(7.69)$ & $7.71(4.40)$ \\
\hline $\mathrm{FM}^{3, \mathrm{a}}$ & $6.05(2.46)$ & $5.01(1.81)$ & $7.17(3.75)$ & $10.81(5.45)$ & 72.19 (7.53) \\
\hline$\% \mathrm{BF}^{3}$ & $26.19(7.50)$ & $23.63(3.71)$ & $26.21(7.18)$ & $33.04(7.69)$ & $29.81(7.53)$ \\
\hline
\end{tabular}

Table 2 Anthropometric and body composition variables for urban Mexican Maya children

6

$7 \quad{ }^{1}$ Stunted defined as height-for-age less than the $5^{\text {th }}$ percentile of Frisancho's Comprehensive

8 reference using NHANES III (2008).

$9 \quad{ }^{2}$ Age and sex specific z-scores based upon Frisancho's Comprehensive reference (2008).

$10{ }^{3}$ Calculated using an equation for American Indian children including bioelectrical impedance and 11 anthropometry (Lohman et al 1999).

12 a Significant difference found between stunted and non-stunted children using an independent $t$-test, $13 p<0.01$ 
$3 \quad$ Table 3 Energy expenditure variables for urban Mexican Maya children

\begin{tabular}{|c|c|c|c|c|c|c|}
\hline & & \multicolumn{2}{|c|}{ Stunted } & \multicolumn{2}{|c|}{ Non-Stunted } & \multirow{2}{*}{ All } \\
\hline & & Boys & Girls & Boys & Girls & \\
\hline \multirow{2}{*}{$\begin{array}{l}\text { Resting } \\
\text { energy } \\
\text { expenditur } \\
\mathrm{e}^{2}\end{array}$} & kJ/day & $\begin{array}{l}4221.00 \\
(315.23)\end{array}$ & $\begin{array}{l}3813.17 \\
(384.53)\end{array}$ & $\begin{array}{l}4542.25 \\
(437.84)\end{array}$ & $\begin{array}{l}4615.90 \\
(615.36)\end{array}$ & $\begin{array}{l}4383.33 \\
(547.15)\end{array}$ \\
\hline & $\underset{b}{\mathrm{~kJ} / \mathrm{kg} / \mathrm{day}}$ & $\begin{array}{l}188.89 \\
(15.02)\end{array}$ & $\begin{array}{l}185.99 \\
(18.34)\end{array}$ & $\begin{array}{l}176.31 \\
(15.05)\end{array}$ & $\begin{array}{l}153.24 \\
(19.44)\end{array}$ & $\begin{array}{l}172.98 \\
(21.50)\end{array}$ \\
\hline \multirow{2}{*}{$\begin{array}{l}\text { Activity } \\
\text { energy } \\
\text { expenditur } \\
\mathrm{e}^{2}\end{array}$} & kJ/day & $\begin{array}{l}2022.20 \\
(257.92)\end{array}$ & $\begin{array}{l}2340.50 \\
(425.36)\end{array}$ & $\begin{array}{l}3711.67 \\
(955.11)\end{array}$ & $\begin{array}{l}3411.60 \\
(799.06)\end{array}$ & $\begin{array}{l}3272.27 \\
(879.21)\end{array}$ \\
\hline & $\underset{\mathrm{d}}{\mathrm{kJ} / \mathrm{kg} / \mathrm{day}}$ & $\begin{array}{l}135.97 \\
(15.19)\end{array}$ & $\begin{array}{l}114.26 \\
(13.51)\end{array}$ & $\begin{array}{l}143.10 \\
(32.08)\end{array}$ & $\begin{array}{l}112.09 \\
(18.51)\end{array}$ & $\begin{array}{l}127.38 \\
(26.78)\end{array}$ \\
\hline \multirow{2}{*}{$\begin{array}{l}\text { Total } \\
\text { energy } \\
\text { expenditur } \\
\mathrm{e}^{2}\end{array}$} & kJ/day & $\begin{array}{l}8060.40 \\
(594.34)\end{array}$ & $\begin{array}{l}6859.83 \\
(858.29)\end{array}$ & $\begin{array}{c}9,171.00 \\
(1393.84)\end{array}$ & $\begin{array}{c}8919.50 \\
(1487.21)\end{array}$ & $\begin{array}{c}8506.30 \\
(1485.79)\end{array}$ \\
\hline & $\underset{\mathrm{d}}{\mathrm{kJ} / \mathrm{kg} / \mathrm{day}}$ & $\begin{array}{l}360.95 \\
(32.28)\end{array}$ & $\begin{array}{c}333.62 \\
(30.23)\end{array}$ & $\begin{array}{l}354.90 \\
(42.56)\end{array}$ & $\begin{array}{l}294.81 \\
(36.81)\end{array}$ & $\begin{array}{c}33373 \\
(45.13)\end{array}$ \\
\hline \multirow{2}{*}{ MET $(\min )^{3}$} & $\begin{array}{l}\text { Light } \\
(<3)^{a, c}\end{array}$ & $\begin{array}{l}1327.00 \\
(29.65)\end{array}$ & $\begin{array}{c}1380.33 \\
(40.81)\end{array}$ & $\begin{array}{c}1275.92 \\
(70.63)\end{array}$ & $\begin{array}{c}1323.10 \\
(52.93)\end{array}$ & $\begin{array}{c}1316.94 \\
(65.46)\end{array}$ \\
\hline & $\begin{array}{l}\text { Mod-Vig } \\
(\geq 3)^{a, c}\end{array}$ & $\begin{array}{l}113.60 \\
(29.84)\end{array}$ & $\begin{array}{c}60.00 \\
(40.09)\end{array}$ & $\begin{array}{l}164.25 \\
(70.30)\end{array}$ & $\begin{array}{l}116.70 \\
(52.74)\end{array}$ & $\begin{array}{l}123.21 \\
(65.21)\end{array}$ \\
\hline
\end{tabular}

$4{ }^{1}$ Stunted defined as height-for-age less than the $5^{\text {th }}$ percentile of Frisancho's Comprehensive

5 reference using NHANES III (2008).

$6{ }^{2}$ Calculated in the Actiheart software using simultaneous heart rate and accelerometry data and an 7 external reference curve (Corder 2005).

$8{ }^{3}$ Average number of minutes per day spent at each MET level

9 a Significant difference found between stunted and non-stunted children using an independent $t$-test, $10 p<0.05$

11 bignificant difference found between stunted and non-stunted children using an independent $t$-test, $12 p<0.01$

$13{ }^{\mathrm{c}}$ Significant difference found between the sexes using an independent $t$-test, $p<0.05$

14 d Significant difference found between the sexes using an independent $t$-test, $p<0.01$ 
Table 4 Estimated measures of energy expenditure predicted by absolute fat free mass, stature and sex in urban Mexican Maya children using multiple linear regression

\begin{tabular}{|c|c|c|c|c|c|c|c|c|c|c|c|c|c|c|c|c|c|c|}
\hline & \multicolumn{6}{|c|}{ Resting energy expenditure (kJ/day) } & \multicolumn{6}{|c|}{ Activity energy expenditure (kJ/day) } & \multicolumn{6}{|c|}{ Total energy expenditure (kJ/day) } \\
\hline & \multicolumn{2}{|c|}{ Model 1} & \multicolumn{2}{|c|}{ Model 2} & \multicolumn{2}{|c|}{ Model 3} & \multicolumn{2}{|c|}{ Model 1} & \multicolumn{2}{|c|}{ Model 2} & \multicolumn{2}{|c|}{ Model 3} & \multicolumn{2}{|c|}{ Model 1} & \multicolumn{2}{|c|}{ Model 2} & \multicolumn{2}{|c|}{ Model 3} \\
\hline & $\mathrm{B}(\mathrm{SE})$ & $P$ & $\mathrm{~B}(\mathrm{SE})$ & $P$ & $\mathrm{~B}(\mathrm{SE})$ & $P$ & $\mathrm{~B}(\mathrm{SE})$ & $P$ & $\mathrm{~B}(\mathrm{SE})$ & $P$ & $\mathrm{~B}(\mathrm{SE})$ & $P$ & $\mathrm{~B}(\mathrm{SE})$ & $P$ & $\mathrm{~B}(\mathrm{SE})$ & $P$ & $\mathrm{~B}(\mathrm{SE})$ & $P$ \\
\hline Constant & $\begin{array}{l}1297.51 \\
(264.34)\end{array}$ & $<0.001$ & $\begin{array}{l}1675.07 \\
(367.88)\end{array}$ & $<0.001$ & $\begin{array}{l}1716.65 \\
(338.84)\end{array}$ & $<0.001$ & $\begin{array}{c}-10.10 \\
(798.22)\end{array}$ & 0.990 & $\begin{array}{c}1526.13 \\
(1078.69)\end{array}$ & 0.167 & $\begin{array}{l}1646.29 \\
(994.72)\end{array}$ & 0.109 & $\begin{array}{c}1430.70 \\
(1087.01)\end{array}$ & 0.198 & $\begin{array}{c}3556.42 \\
(1465.73)\end{array}$ & 0.021 & $\begin{array}{c}3736.13 \\
(1323.30)\end{array}$ & 0.009 \\
\hline FFM $(\mathrm{kg})^{1,2}$ & $\begin{array}{l}167.48 \\
(14.17)\end{array}$ & $<0.001$ & $\begin{array}{l}152.23 \\
(17.46)\end{array}$ & $<0.001$ & $\begin{array}{l}154.77 \\
(16.09)\end{array}$ & $<0.001$ & $\begin{array}{l}178.15 \\
(42.79)\end{array}$ & $<0.001$ & $\begin{array}{l}116.08 \\
(51.18)\end{array}$ & 0.031 & $\begin{array}{l}123.42 \\
(47.33)\end{array}$ & 0.014 & $\begin{array}{l}384.02 \\
(58.27)\end{array}$ & $<0.001$ & $\begin{array}{l}298.14 \\
(69.55)\end{array}$ & $<0.001$ & $\begin{array}{l}309.11 \\
(62.84)\end{array}$ & $<0.001$ \\
\hline $\begin{array}{l}\text { Height z- } \\
\text { score }^{3}\end{array}$ & & & $\begin{array}{c}81.35 \\
(56.13)\end{array}$ & 0.158 & $\begin{array}{c}78.29 \\
(51.65)\end{array}$ & 0.140 & & & $\begin{array}{c}330.99 \\
(164.57)\end{array}$ & 0.053 & $\begin{array}{c}322.15 \\
(151.93)\end{array}$ & 0.043 & & & $\begin{array}{c}458.00 \\
(223.62)\end{array}$ & 0.049 & $\begin{array}{c}444.79 \\
(201.71)\end{array}$ & 0.036 \\
\hline $\operatorname{Sex}^{4}$ & & & & & $\begin{array}{c}-189.81 \\
(74.76)\end{array}$ & 0.017 & & & & & $\begin{array}{l}-548.45 \\
(219.92)\end{array}$ & 0.019 & & & & & $\begin{array}{l}-820.22 \\
(29.98)\end{array}$ & 0.009 \\
\hline $\mathrm{R}^{2}$ adj & \multicolumn{2}{|c|}{0.813} & \multicolumn{2}{|c|}{0.819} & \multicolumn{2}{|c|}{0.847} & \multicolumn{2}{|c|}{0.338} & \multicolumn{2}{|c|}{0.397} & \multicolumn{2}{|c|}{0.486} & \multicolumn{2}{|c|}{0.570} & \multicolumn{2}{|c|}{0.610} & \multicolumn{2}{|c|}{0.683} \\
\hline Constant & $\begin{array}{l}1297.51 \\
(264.34)\end{array}$ & $<$ & $\begin{array}{l}1322.66 \\
(341.02)\end{array}$ & 0.001 & $\begin{array}{l}1310.45 \\
(314.92)\end{array}$ & $<0.001$ & $\begin{array}{c}-10.10 \\
(798.22)\end{array}$ & 0 & $\begin{array}{c}851.06 \\
(997.89)\end{array}$ & 0.400 & $\begin{array}{c}818.43 \\
(937.75)\end{array}$ & 0.390 & $\begin{array}{c}1430.70 \\
(1087.01)\end{array}$ & 0.198 & $\begin{array}{c}2415.07 \\
(1371.99)\end{array}$ & 0.089 & $\begin{array}{c}2365.24 \\
(1263.20)\end{array}$ & 0.071 \\
\hline FFM (kg) & $\begin{array}{l}167.48 \\
(14.17)\end{array}$ & $<0.001$ & $\begin{array}{l}166.35 \\
(17.24)\end{array}$ & $<0.001$ & $\begin{array}{l}171.50 \\
(16.05)\end{array}$ & $<0.001$ & $\begin{array}{l}178.15 \\
(42.79)\end{array}$ & $<0.001$ & $\begin{array}{c}139.302 \\
(50.45)\end{array}$ & 0.010 & $\begin{array}{l}153.08 \\
(47.80)\end{array}$ & 0.003 & $\begin{array}{l}384.02 \\
(58.27)\end{array}$ & $<0.001$ & $\begin{array}{l}339.62 \\
(69.36)\end{array}$ & $<0.001$ & $\begin{array}{l}360.65 \\
(64.39)\end{array}$ & $<0.001$ \\
\hline Stunted $^{5,6}$ & & & $\begin{array}{c}-12.74 \\
(106.43)\end{array}$ & 0.906 & $\begin{array}{c}22.48 \\
(99.29)\end{array}$ & 0.822 & & & $\begin{array}{c}-436.32 \\
(311.43)\end{array}$ & 0.171 & $\begin{array}{l}-342.24 \\
(295.65)\end{array}$ & 0.256 & & & $\begin{array}{l}-498.75 \\
(428.18)\end{array}$ & 0.253 & $\begin{array}{l}-355.09 \\
(398.26)\end{array}$ & 0.380 \\
\hline Sex & & & & & $\begin{array}{c}-194.98 \\
(78.38)\end{array}$ & 0.019 & & & & & $\begin{array}{l}-520.80 \\
(233.40)\end{array}$ & 0.034 & & & & & $\begin{array}{l}-798.56 \\
(314.40)\end{array}$ & 0.017 \\
\hline $\mathrm{R}^{2}$ adj & \multicolumn{2}{|c|}{0.813} & \multicolumn{2}{|c|}{0.806} & 0.8 & & \multicolumn{2}{|c|}{0.338} & \multicolumn{2}{|c|}{0.358} & 0.4 & & \multicolumn{2}{|c|}{0.570} & \multicolumn{2}{|c|}{0.575} & \multicolumn{2}{|c|}{0.640} \\
\hline
\end{tabular}

${ }^{1}$ Fat free mass expressed as kilograms of body weight

${ }^{2}$ Calculated using an equation for American Indian children including bioelectrical impedance and anthropometry

${ }^{3}$ Height-for-age z-scores calculated using the age and sex specific curves of Frisancho's Comprehensive reference (2008).

${ }^{4}$ Boys set as reference

${ }^{5}$ Non-stunted set as reference

${ }^{6}$ Stunted defined as height-for-age less than the $5^{\text {th }}$ percentile of Frisancho's Comprehensive reference (2008). 